\title{
Assessment of Coagulation-Flocculation Process Efficiency for the Natural Organic Matter Removal in Drinking Water Treatment
}

\author{
Corina Petronela Mustereț, Irina Morosanu (1), Ramona Ciobanu, Oana Plavan, Andreea Gherghel, Malek Al-Refai, \\ Ioana Roman and Carmen Teodosiu*
}

check for updates

Citation: Musteret, C.P.; Morosanu, I.; Ciobanu, R.; Plavan, O.; Gherghel, A.; Al-Refai, M.; Roman, I.; Teodosiu, C. Assessment of Coagulation-Flocculation Process Efficiency for the Natural Organic Matter Removal in Drinking Water Treatment. Water 2021, 13, 3073. https://doi.org/10.3390/w13213073

Academic Editor: Alexandre T. Paulino

Received: 5 October 2021

Accepted: 30 October 2021

Published: 2 November 2021

Publisher's Note: MDPI stays neutral with regard to jurisdictional claims in published maps and institutional affiliations.

Copyright: (c) 2021 by the authors. Licensee MDPI, Basel, Switzerland. This article is an open access article distributed under the terms and conditions of the Creative Commons Attribution (CC BY) license (https:/ / creativecommons.org/licenses/by/ $4.0 /)$.
Department of Environmental Engineering and Management, "Cristofor Simionescu" Faculty of Chemical Engineering and Environmental Protection, "Gheorghe Asachi" Technical University of Iasi, 73 D. Mangeron Street, 700050 Iasi, Romania; corina_musteret@ch.tuiasi.ro (C.P.M.); morosanu.irina@gmail.com (I.M.); ramona.ciobanu@student.tuiasi.ro (R.C.); oana.plavan@ch.tuiasi.ro (O.P.); andreea.gherghel@ch.tuiasi.ro (A.G.); malek-mohamed-yousef.al-refai@student.tuiasi.ro (M.A.-R.); ioana.roman983@gmail.com (I.R.)

* Correspondence: cteo@ch.tuiasi.ro

Abstract: Natural organic matter (NOM) represents a range of heterogeneous hydrophobic and hydrophilic components naturally occurring in the water source and, due to the fact that they can act as precursors for the disinfection, by-products may have a considerable impact on drinking water quality. Coagulation-flocculation $(\mathrm{C} / \mathrm{F})$ is among the most applied processes for NOM removal from water sources (especially rivers). In this study, $\mathrm{C} / \mathrm{F}$ efficiency for a river water supply was investigated in cold and warm conditions, by varying the coagulant dose and mixing conditions. In this study, polyhydroxy aluminum chloride PAX XL 60, and polyacrylamide FloPam AN 910 SEP were used as coagulant and flocculant, respectively. Multiple water quality indicators were determined, such as turbidity, chemical oxygen demand (COD), dissolved organic carbon (DOC), and residual aluminum concentration. Some unconventional parameters relevant for NOM removal were also considered, like absorbance at $254 \mathrm{~nm}$ (A254), at $280 \mathrm{~nm}$ (A280), and at $365 \mathrm{~nm}$ (A365), as well as the ratios A254/DOC, A254/280, and A254/A365. After coagulation-flocculation, turbidity was completely removed in all the studied conditions. The DOC content was reduced by up to $22.65 \%$ at a low temperature and by up to $31.81 \%$ at a high temperature. After the addition of polyelectrolyte in cold conditions, the efficiency in terms of A254 increased by up to $37.4 \%$, while the specific absorbance decreased. The high molecular weight NOM increased after $\mathrm{C} / \mathrm{F}$, based on the A254/A365 ratio. Chemometric analysis was employed in order to determine the effect of the coagulant dose on the process efficiency. The optimum coagulation-flocculation conditions were corroborated by means of the principal component analysis.

Keywords: coagulation; natural organic matter; surface water; dissolved organic carbon; water quality indicators; polyhydroxy aluminum chloride

\section{Introduction}

Natural organic matter (NOM) is present in most of the surface water supplies, along with suspended particles, colloids, and pathogens. Natural organic matter is defined as a complex matrix of heterogeneous hydrophobic and hydrophilic components, naturally occurring in the water sources, as a result of different hydrological, biological, and geological interaction schemes [1-3]. NOM has a wide variety of chemical compositions, molecular sizes, functional group chemistries, solubilities, and polarities [2,4]. As a result of its composition, NOM does not have a set of defined functional groups, size distributions, acid-base functionalities, or chelating potentials [5].

The presence of natural organic matter in sources adequate for drinking water treatment, mainly humic acid and fulvic acid, contributes to the formation of disinfection 
by-products (DBPs), when water is treated with a disinfecting agent, such as chlorine or chloramine, which leads to the potential presence of carcinogenic compounds in conventionally treated waters (involving chlorination as the final stage of raw water treatment). These DBPs in drinking water, including aliphatic halogenated trihalomethanes (THMs), haloacetonitriles, and haloacetic acids (HAAs), have been found to be toxic and associated with many forms of cancer, endocrine disorders, or other diseases [6,7]. Due to the public concerns regarding the potential health effects of DBPs, the European Union (EU) regulated THMs, setting their limit at $100 \mu \mathrm{g} / \mathrm{L}$ [8]. In order to comply with EU regulations, the Romanian Government has set the same limit. Thus, the concentration of NOM from raw water must be reduced as much as possible, prior to the disinfection process, to minimize the formation of DBPs.

Numerous technologies have been employed to remove NOM in the treatment of drinking water, such as coagulation and flocculation $(\mathrm{C} / \mathrm{F})$, activated carbon adsorption, advanced oxidation, and membrane processes [4], but the most common and feasible drinking water processes are considered to be coagulation and flocculation, followed by sedimentation and sand filtration.

Coagulation is based on NOM particle destabilization using positively charged metals, with the formation of larger particles (flocs), followed by the settling of the organic pollutants. This is usually carried out with alum $\left(\mathrm{Al}_{2}\left(\mathrm{SO}_{4}\right)_{3}\right)$ or ferric chloride $\left(\mathrm{FeCl}_{3}\right)$. The treatment of raw water in dry, cold (winter) conditions is especially difficult, since the coagulation process becomes hindered due to the adverse effects of low temperatures on the coagulation rate, coagulant dose, and structure of the formed flocs [9]. In addition, low turbidity means low concentration and the dimension of colloidal matter existing in the raw water. This further imposes on its removal using the above mentioned coagulants. In recent years, Al-based polymers are increasingly used in practice, as they have proved to be less sensitive to $\mathrm{pH}$ and temperature variation [10]. Furthermore, the coagulant dose needs to be optimized, in order to avoid the low-quality of the finished water, and even greater environmental (e.g., high sludge production) or human health (e.g., the potential of Alzheimer's disease) impacts [6].

Polyhydroxy aluminum chloride ( $\mathrm{PACl})$ contains highly positive charged polycations, such as $\mathrm{Al}^{3+},\left[\mathrm{Al}_{2}(\mathrm{OH})_{2}\right]^{4+},\left[\mathrm{Al}_{8}(\mathrm{OH})_{20}\right]^{4+},\left[\mathrm{AlO}_{4} \mathrm{Al}_{12}(\mathrm{OH})_{24}\left(\mathrm{H}_{2} \mathrm{O}\right)_{12}\right]^{7+}$, and other species $[11,12]$. These species have a great neutralization and destabilizing effect of NOM. An important characteristic of $\mathrm{PACl}$ coagulants is basicity, which controls the nature of the polymeric portion in $\mathrm{PACl}$ [13]. Several authors have investigated the influence of PACl basicity on coagulation efficacy. Zhang et al. [14] evaluated several synthesized PACl with basicity values between 63.4 and $90.3 \%$ in the coagulation process of a low temperature and low turbidity water. They observed a decrease in turbidity with an increase in PACl basicity. Another study reported a better turbidity removal with an increase in $\mathrm{PACl}$ basicity for a humic acid artificial water [15]. Moreover, the research of Yan et al. [16] indicated only a relatively better removal of NOM when using $\mathrm{PACl}$ with various basicity values on hydrophilic river waters with different alkalinities. The non-linear effect of PACl basicity on the coagulation performance in surface water treatment was also observed by Yang et al. [17]. Since the results are not conclusive, more research is needed regarding the efficiency of $\mathrm{PACl}$ coagulants having diverse basicity values, when applied to treating raw water with specific characteristics.

In real applications, the efficiency of coagulation and flocculation to remove NOM from surface water mainly depends on the coagulant's type and dosage, $\mathrm{pH}$ value, mixing conditions, the water's temperature, and the flocculant's type and dosage, on one hand, and the properties of the NOM, on the other hand. It is known that low molecular weight NOM (i.e., hydrophilic moieties) usually require a higher coagulant dose than higher molecular weight NOM. This is because these compounds present a higher polarity and water solubility [4].

To better assess the nature of NOM and to successfully monitor these compounds throughout the technological processes, a few general parameters, including dissolved 
organic carbon (DOC), UV/Vis absorbance, and specific UV absorbance (SUVA), may be used $[18,19]$.

The absorbance values recorded at different wavelengths, such as $254 \mathrm{~nm}, 280 \mathrm{~nm}$, and $365 \mathrm{~nm}$, are cited to distinguish the presence of certain components of NOM. Ratios of different absorbance values, like A254/A280 and A254/A365, represent specific parameters, which may be used to evaluate part of some humic substances with certain characteristics from a given sequence, e.g., the molecular weight, the high hydrophilic/hydrophobic ratio, and the degrees of reactivity in the presence of disinfection agents [19].

The absorbance recorded at a $254 \mathrm{~nm}$ wavelength (A254) indicates the concentration of organic compounds with aromatic groups or with extended conjugation $[5,18]$.

The absorbance recorded at $\lambda=280 \mathrm{~nm}$ (A280) informs us of the presence of some unsaturated compounds with double bonds, $\pi-\pi^{*}$ interactions, and aromatic compounds with a high reactivity, which can interact with disinfection agents and form THMs. The A280 is associated, in particular, with the presence of precursors of THMs and HAAs [19].

The absorbance at $365 \mathrm{~nm}$ (A365) is a parameter correlated with the presence of aquatic humic compounds. It indicates the presence of some compounds resulting from aquatic heterotrophic metabolism, compounds with aromatic character, and nitrogen based functional groups. These compounds have a higher molecular weight and a more pronounced hydrophobic character in comparison with compounds characterized by A254 and A280 parameters [19].

SUVA, expressed in $\mathrm{L} / \mathrm{mg} \cdot \mathrm{m}$, is the ratio of absorbance at $\lambda=254 \mathrm{~nm}$ and the DOC concentration of the water sample $[18,19]$. A SUVA value of $>4$ indicates the presence of mainly hydrophobic and especially aromatic NOM, whilst a SUVA value of $<3$ suggests the existence of mainly hydrophilic NOM in raw water and drinking water $[18,20]$.

The A254/A280 ratio allows the assessment of the compounds with the formation potential of THMs and HAAs during disinfection. The values of this ratio of approximately 1 indicate the predominant presence of compounds that can easily interact with chlorine [19]. The A254/ A365 ratio can be correlated with the SUVA parameter, and the high values for the A254/A365 ratio are associated with the low values for SUVA [19].

This study presents a series of experiments obtained on a laboratory scale set up for the coagulation-flocculation of surface water from the Prut River, which is the drinking water supply for a city in northern Romania. The objectives of this study are: (a) to investigate the influence of the operational process parameters and water quality indicators (conventional and non-conventional, relevant for NOM removal) on the process performances in terms of removal efficiencies; (b) to select the optimum operating parameters for NOM removal under cold and warm conditions; and (c) to correlate the optimum coagulation-flocculation conditions (determined by laboratory experiments) with the principal component analysis. By means of an integrated approach, this study considers both the experimental coagulation-flocculation process efficiencies for NOM removal and the determination of the optimum conditions, with their statistical relevance.

\section{Materials and Methods}

\subsection{Water Sampling and Characteristics}

In order to evaluate the quality of the raw water from the drinking water treatment plant, the minimum, average, and maximum annual values of the quality indicators for the time period 2013-2020 were analyzed. The general characteristics of the raw water, namely the $\mathrm{pH}$ levels, oxidability (chemical oxygen demand, COD, determined with $\mathrm{KMnO}_{4}$ ), conductivity, turbidity, total hardness, ammonia, nitrates, nitrites, sulphates, and iron, are presented in Table 1. It was observed that the raw water quality does not always comply with the legislative requirements for conductivity, turbidity, and iron. Moreover, the average values for the turbidity and iron are between $5.8 \%$ and $169 \%$ higher than the maximum allowed concentrations (MACs). Meanwhile, the maximum recorded values were found to exceed the MACs by almost 5 times for iron and 7 times for turbidity, respectively. 
Table 1. General raw water characteristics in the period 2013-2020.

\begin{tabular}{|c|c|c|c|c|c|c|c|c|c|c|c|}
\hline \multicolumn{2}{|c|}{$\begin{array}{l}\text { Quality } \\
\text { Indicator }\end{array}$} & $\mathrm{pH}$ & $\begin{array}{l}\text { Conductivity } \\
\left(\text { at } 20^{\circ} \mathrm{C}\right)\end{array}$ & Turbidity & $\begin{array}{c}\text { COD } \\
\text { (Permanganate } \\
\text { Index) }\end{array}$ & $\begin{array}{c}\text { Total } \\
\text { Hardness }\end{array}$ & $\mathrm{NH}_{4}{ }^{+}$ & $\mathrm{NO}_{3}{ }^{-}$ & $\mathrm{NO}_{2}{ }^{-}$ & $\mathrm{SO}_{4}^{2-}$ & $\mathbf{F e}$ \\
\hline \multicolumn{2}{|c|}{ Unit } & pH Units & $\mu \mathrm{S} / \mathrm{cm}$ & UNT & $\mathrm{mg} \mathrm{O}_{2} / \mathrm{L}$ & ${ }^{\circ} \mathrm{Ge}$ & $\mathrm{mg} / \mathrm{L}$ & $\mathrm{mg} / \mathrm{L}$ & $\mathrm{mg} / \mathrm{L}$ & $\mathrm{mg} / \mathrm{L}$ & $\mu \mathrm{g} / \mathrm{L}$ \\
\hline \multirow{4}{*}{2013} & $\min$ & 7.1 & 556 & 0.8 & 1.8 & 13.2 & 0.06 & 1.2 & 0.0 & 66.1 & 43 \\
\hline & avg & 7.5 & 848 & 7.02 & 2.1 & 21.25 & 0.21 & 2.0 & 0.02 & 126.2 & 412.4 \\
\hline & $\max$ & 7.9 & 1020 & 24.0 & 2.4 & 27.2 & 0.43 & 3.0 & 0.08 & 156.2 & 885 \\
\hline & $\min$ & 7.0 & 569 & 2.03 & 1.7 & 14.21 & 0.0 & 1.1 & 0 & 77.2 & 87 \\
\hline \multirow[t]{3}{*}{2014} & avg & 7.3 & 841 & 9.19 & 2.3 & 21.47 & 0.18 & 2.3 & 0.02 & 122 & 538 \\
\hline & $\max$ & 8.0 & 1094 & 20.4 & 2.7 & 30.8 & 0.47 & 3.4 & 0.06 & 185.8 & 1139 \\
\hline & $\min$ & 7.3 & 510 & 1.3 & 1.8 & 13.2 & 0.04 & 1.7 & 0.01 & 53.4 & 28 \\
\hline \multirow{3}{*}{2015} & avg & 7.5 & 676 & 4.9 & 2.2 & 21.45 & 0.08 & 2.3 & 0.01 & 94.6 & 355 \\
\hline & $\max$ & 8.0 & 973 & 13.7 & 2.5 & 31.6 & 0.15 & 3.0 & 0.02 & 167.2 & 846 \\
\hline & $\min$ & 7.6 & 227 & 1.98 & 2.0 & 8.81 & 0.0 & 1.4 & 0.0 & 20.4 & 37 \\
\hline \multirow[t]{3}{*}{2016} & avg & 7.8 & 515 & 7.86 & 2.2 & 14.72 & 0.04 & 2.2 & 0.004 & 68.8 & 241 \\
\hline & $\max$ & 8.3 & 817 & 20.4 & 2.8 & 21.35 & 0.1 & 3.0 & 0.01 & 126.7 & 905 \\
\hline & $\min$ & 7.2 & 401 & 1.02 & 1.8 & 11.2 & 0 & 2.2 & 0.002 & 35.5 & 43 \\
\hline \multirow{3}{*}{2017} & avg & 7.8 & 595 & 6.45 & 2.5 & 14.13 & 0.03 & 3.1 & 0.01 & 67.6 & 139 \\
\hline & $\max$ & 8.3 & 807 & 25.1 & 3.0 & 20.1 & 0.08 & 3.9 & 0.01 & 113.4 & 319 \\
\hline & $\min$ & 7.4 & 447 & 0.66 & 1.6 & 11.23 & 0.0 & 1.4 & 0.01 & 23.9 & 19 \\
\hline \multirow[t]{3}{*}{2018} & avg & 7.8 & 618 & 5.38 & 2.5 & 14.55 & 0.05 & 3.1 & 0.01 & 58.7 & 78 \\
\hline & $\max$ & 8.3 & 860 & 13.2 & 3.9 & 23.68 & 0.13 & 6.9 & 0.03 & 119.5 & 187 \\
\hline & $\min$ & 6.9 & 488 & 2.8 & 2.1 & 11.67 & 0.05 & 2.6 & 0.009 & 29.8 & 116 \\
\hline \multirow[t]{3}{*}{2019} & avg & 7.7 & 885 & 8.56 & 2.3 & 22.8 & 0.13 & 4.6 & 0.03 & 99.4 & 301.5 \\
\hline & $\max$ & 8.4 & 1400 & 40 & 2.7 & 40.9 & 0.24 & 6.7 & 0.2 & 166.9 & 546 \\
\hline & $\min$ & 7.44 & 419 & 1.46 & 2.0 & 11.45 & 0.02 & 2.9 & 0.006 & 55.5 & 60 \\
\hline \multirow[t]{2}{*}{2020} & avg & 8.04 & 743 & 5.29 & 2.2 & 16.62 & 0.11 & 5.1 & 0.02 & 92.0 & 142.4 \\
\hline & $\max$ & 8.4 & 1182 & 28.8 & 2.4 & 29.87 & 0.18 & 7.8 & 0.05 & 175.5 & 267 \\
\hline \multicolumn{2}{|c|}{$\begin{array}{l}\text { MAC*(Law } \\
458 / 2002)[21]\end{array}$} & $\geq 6.5 ; \leq 9.5$ & 2500 & $\leq 5$ & 5 & $\operatorname{Min} 5$ & 0.5 & 50 & 0.5 & 250 & 200 \\
\hline
\end{tabular}

Raw water samples for the coagulation-flocculation tests were collected from the water from the drain of the Prut River during a cold, dry season (December). The water parameters were analyzed according to the current Romanian Standard Methods for water quality analysis. Furthermore, the following unconventional parameters were calculated for monitoring the coagulation process: SUVA, A254/A280, and A254/A365.

\subsection{Chemicals and Instruments}

The water characteristics were determined in the Laboratory for Environmental Control and Analysis (LACMED) that is accredited by the Romanian Association for Accreditation (RENAR), under SR EN ISO/CEI 17025/2018. The total organic carbon (TOC) and dissolved organic carbon levels were measured using a Shimadzu VCPN-TNM1 TOC system. The A254, A280, and A365 were measured by a spectrophotometer (UV-VIS JASCO 630), using a quartz cell with a $1 \mathrm{~cm}$ path length, after filtration through a $0.45 \mu \mathrm{m}$ membrane. Turbidity was measured using a 93703-11 HANNA HI turbidimeter, and the $\mathrm{pH}$ was measured using a C863 CONSORT multi-parameter, which was calibrated daily. Metal elements ( $\mathrm{Fe}$ and $\mathrm{Al}$ ) were analyzed using ContrAA 800G atomic absorption spectrometer (Analytik Jena), and the chemical oxygen demand was determined by a standard method (SR EN ISO 8467-2001).

The coagulation-flocculation experiments were carried out using a conventional jar test equipment (model JLT6 from VELP Scientifica) provided with a flat paddle impeller and variable speed.

The chemicals used for the experiments were polyhydroxy aluminum chloride ( $\mathrm{PACl})$, with the commercial name PAX XL 60 (Kemcristal, Romania), and polyacrylamide, with the commercial name FloPam AN 910 SEP (SNF, UK). Both chemicals were courteously provided by the local drinking water operator. PAX XL 60 is a medium basicity coagulant, with the formula $\mathrm{Al}(\mathrm{OH})_{x}(\mathrm{CL})_{3-\mathrm{x}}$ (where $\mathrm{x}$ is in the range $0-2.3$, typically $\mathrm{x}>0.5$ ). Additional characteristics of the coagulant can be found in Table S1, provided in the Supplementary Material of this article. The flocculant FloPam AN 910 SEP is an anionic polyacrylamide with a low charge density, very high molecular weight, and a $\mathrm{pH}$ of 6-8 (for $5 \mathrm{~g} / \mathrm{L}$ ). 


\subsection{Jar Test Procedure}

In order to determine the optimal coagulant dose, coagulation-flocculation jar tests were performed, using raw water samples of $700 \mathrm{~mL}$. The polyhydroxy aluminum chloride PAX XL 60 and the polyacrylamide FloPam AN 910 SEP were used as coagulant and flocculant (coagulant aid), respectively. All six coagulation-flocculation tests were realized at the natural $\mathrm{pH}$ level of the raw water. Several parameters, such as the coagulant dose, the river water temperature, the rapid and slow mixing time, and the presence or absence of the flocculant, were investigated. The coagulant dose varied in the range 50-200 $\mu \mathrm{L} / \mathrm{L}$ (corresponding to $2-7 \mathrm{mg} \mathrm{Al} / \mathrm{L}$ ). Table 2 briefly presents the working conditions for the coagulation-flocculation tests.

Table 2. Conditions for experimental testing.

\begin{tabular}{|c|c|c|c|c|c|}
\hline \multirow{2}{*}{$\begin{array}{l}\text { Tests } \\
\text { Series }\end{array}$} & \multirow{2}{*}{$\begin{array}{l}\text { PACl Dose } \\
\text { (mg Al/L) }\end{array}$} & \multirow{2}{*}{$\mathrm{T}\left({ }^{\circ} \mathrm{C}\right)$} & \multirow{2}{*}{$\begin{array}{l}\text { Coagulant } \\
\text { Aid (mL/L) }\end{array}$} & \multicolumn{2}{|c|}{ Stirring Conditions } \\
\hline & & & & Time of Rapid Mixing & Time of Slow Mixing \\
\hline $\mathrm{T} 1$ & $2-7$ & 4 & 0 & $3 \mathrm{~min}$ at $300 \mathrm{rpm}$ & $15 \mathrm{~min}$ at $60 \mathrm{rpm}$ \\
\hline $\mathrm{T} 2$ & $2-7$ & 4 & 0.05 & $3 \mathrm{~min}$ at $300 \mathrm{rpm}$ & $15 \mathrm{~min}$ at $60 \mathrm{rpm}$ \\
\hline T3 & $2-7$ & 20 & 0 & $3 \mathrm{~min}$ at $300 \mathrm{rpm}$ & $15 \mathrm{~min}$ at $60 \mathrm{rpm}$ \\
\hline $\mathrm{T} 4$ & $2-7$ & 20 & 0.05 & $3 \mathrm{~min}$ at $300 \mathrm{rpm}$ & $15 \mathrm{~min}$ at $60 \mathrm{rpm}$ \\
\hline T5 & $2-7$ & 4 & 0.05 & $1.5 \mathrm{~min}$ at $300 \mathrm{rpm}$ & $10 \mathrm{~min}$ at $60 \mathrm{rpm}$ \\
\hline T6 & $2-7$ & 4 & 0.05 & $3 \mathrm{~min}$ at $200 \mathrm{rpm}$ & $15 \mathrm{~min}$ at $25 \mathrm{rpm}$ \\
\hline $\mathrm{T} 7$ & $2-7$ & 20 & 0.05 & $1.5 \mathrm{~min}$ at $300 \mathrm{rpm}$ & $10 \mathrm{~min}$ at $60 \mathrm{rpm}$ \\
\hline T8 & $2-7$ & 20 & 0.05 & $3 \mathrm{~min}$ at $200 \mathrm{rpm}$ & $15 \mathrm{~min}$ at $25 \mathrm{rpm}$ \\
\hline
\end{tabular}

After settling was completed, the samples of treated water were collected from the supernatant and analyzed. The removal efficiency (RE) of the coagulation-flocculation process was calculated using Equation (1), for a series of conventional water quality indicators, i.e., turbidity, COD, DOC, and residual aluminum concentration, and some unconventional parameters (A254, A280, and A365). The parameter of SUVA and the ratios A254/A280 and A254/A365 were also calculated:

$$
R E(\%)=\frac{C_{i}-C_{f}}{C_{i}} \times 100
$$

where $C_{i}$ and $C_{f}$ are the initial and the final concentration, for a certain water quality indicator, in $\mathrm{mg} / \mathrm{L}$ or $\mu \mathrm{g} / \mathrm{L}$.

\subsection{Chemometric Methods}

Chemometric analysis of the experimental data was performed by correlation analysis and principal component analysis (PCA). The calculations and plots were made using the statistical language $\mathrm{R}$ (version 1.4.1106, RStudio PBC, Boston, MA, USA). The purpose of the correlation analysis was to determine the influence of the coagulant dose on the coagulationflocculation efficiency at various operating conditions. The correlation maps were created using the corrplot package in R. Red and the blue circles correspond to positive and negative correlations, respectively. The color intensity and size of the circle reflect the magnitude of the correlation coefficients, which appear on the circles (between -1 and +1 ) [22]. The corrplots obtained are illustrated in Figures S4-S7 in the Supplementary Material. PCA is useful for reducing a large amount of data with minimal loss of information by using a set of principal components (PC). Thus, trends and correlations between data that are not easily obvious may appear. The original data covariance matrix in PCA is decomposed into scores (eigenvalues) that classify the samples and loadings (eigenvectors), classifying the descriptors in terms of their separation of the samples [23]. The PC are a combination of variables explaining the largest variation in the experimental data and may not have an obvious physical meaning. In this study, the PCA plots were created using the ggbiplot package in $\mathrm{R}$ and considered the relevant PC with scores over 1, unless otherwise stated. 


\section{Results and Discussion}

\subsection{Water Characterization}

The raw water characteristics are presented in Table 3. The values obtained for the raw water quality indicators are representative of the medium-minimum range of values found in Table 1, and characteristic of the water quality in the dry season.

Table 3. Raw water characteristics.

\begin{tabular}{ccc}
\hline Quality Indicator & Unit & Value \\
\hline pH & Conventional Parameters & \\
\hline Turbidity & unit. $\mathrm{pH}$ & $8.17\left(\right.$ at $\left.21.5^{\circ} \mathrm{C}\right)$ \\
Conductivity $\left(\right.$ at $\left.20^{\circ} \mathrm{C}\right)$ & $\mathrm{UNT}$ & 1.27 \\
$\mathrm{COD}$ (permanganate index) & $\mu \mathrm{S} / \mathrm{cm}$ & 561.0 \\
TOC & $\mathrm{mg} \mathrm{O} / \mathrm{L}$ & 1.69 \\
Total suspended solids & $\mathrm{mg} / \mathrm{L}$ & 2.49 \\
$\mathrm{NH}_{4}{ }^{+}$ & $\mathrm{mg} / \mathrm{L}$ & 49.0 \\
$\mathrm{NO}_{2}{ }^{-}$ & $\mathrm{mg} / \mathrm{L}$ & $<0.05$ \\
$\mathrm{NO}_{3}{ }^{-}$ & $\mathrm{mg} / \mathrm{L}$ & 0.03 \\
Total nitrogen & $\mathrm{mg} / \mathrm{L}$ & 1.39 \\
Sulphates & $\mathrm{mg} / \mathrm{L}$ & $<1.0$ \\
Chloride & $\mathrm{mg} / \mathrm{L}$ & 70.40 \\
Total hardness & $\mathrm{mg} / \mathrm{L}$ & 48.99 \\
Fe & ${ }^{\circ} \mathrm{G}$ & 10.86 \\
$\mathrm{Al}$ & $\mu \mathrm{g} / \mathrm{L}$ & 78.16 \\
& $\mu \mathrm{g} / \mathrm{L}$ & 125.20 \\
\hline A254 & Unconventional Parameters & \\
$\mathrm{A} 280$ & $\mathrm{~cm}{ }^{-1}$ & 0.0333 \\
$\mathrm{~A} 365$ & $\mathrm{~cm}{ }^{-1}$ & 0.0239 \\
SUVA & $\mathrm{cm}{ }^{-1}$ & 0.0048 \\
A254/A280 & $\mathrm{L} /(\mathrm{mg} \cdot \mathrm{m})$ & 1.39 \\
$\mathrm{~A} 254 / \mathrm{A} 365$ & - & 1.39 \\
& - & 6.93 \\
\hline & &
\end{tabular}

The values of the unconventional parameters considered in this study are also shown in Table 3. A water sample containing highly aromatic NOM presents the SUVA values over $4 \mathrm{mg} / \mathrm{L}$ [1]. A value of the SUVA indicator of $1.39 \mathrm{~L} /(\mathrm{mg} \cdot \mathrm{m})$ suggests the presence of hydrophilic organic compounds in large quantities, with a low molecular weight and charge density. The hydrophobic fraction determined at $\lambda=280 \mathrm{~nm}$ is 1.4 times smaller than the total hydrophobic organic compounds (expressed as A254), indicating a high content of unsaturated compounds with double bonds, $\pi-\pi^{*}$ interactions, and high reactivity. The high A254/A365 value suggests a low content of hydrophobic organic compounds with a high molecular mass, when compared to the total NOM identified as A254 [19].

\subsection{Influence of the Coagulant Dose}

The removal efficiencies for the conventional water quality indicators after coagulation tests with a PACl dose of 2-7 mg Al/L are illustrated in Figure 1a,b.

It is evident that the colloids (turbidity) of the water sample were totally removed, independent of temperature. In fact, for all coagulation-flocculation tests in this study, turbidity was eliminated; hence, this indicator will not be mentioned in the rest of this section. 


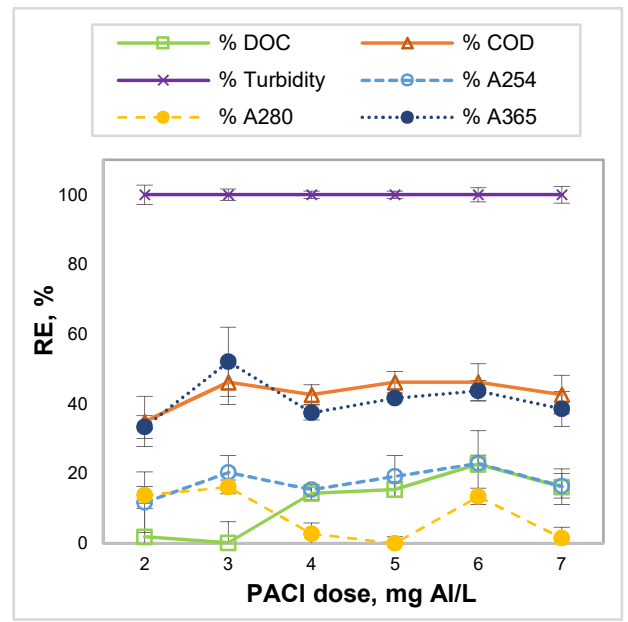

(a)

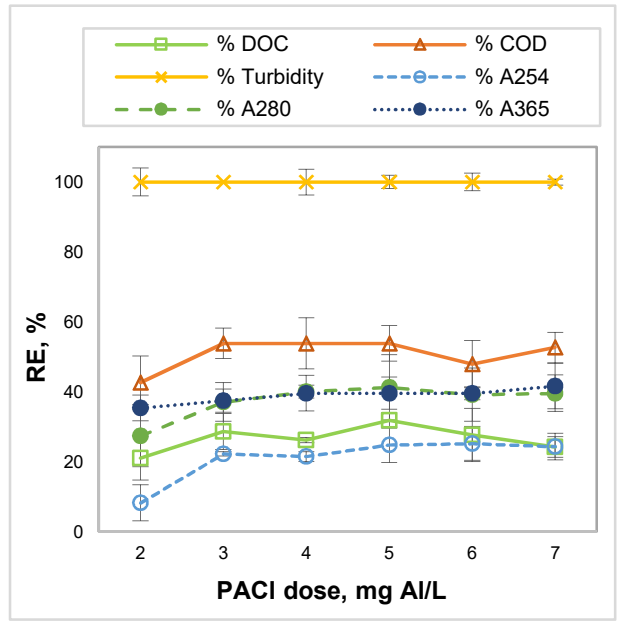

(b)

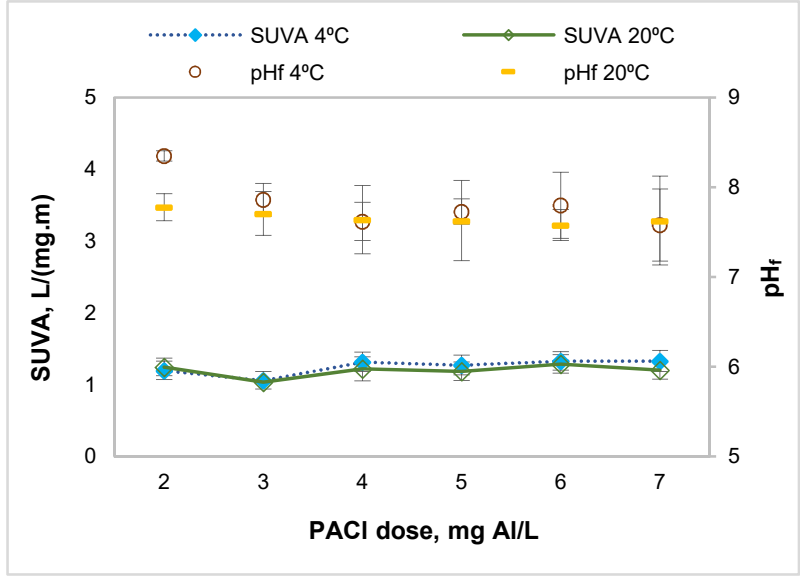

(c)

Figure 1. Removal efficiency of coagulation process at $4{ }^{\circ} \mathrm{C}(\mathbf{a})$ and $20^{\circ} \mathrm{C}(\mathbf{b})$, and the SUVA results (c) for different $\mathrm{PACl}$ doses.

In case of COD, the removal efficiencies were below $53.85 \%$. These values increased first with the coagulant dose, then reached a plateau, while at higher doses they decreased. When using the PACl coagulant for low-DOC river water, ref [24] have observed a decrease in efficiency for the coagulant dose over $3.48 \mathrm{mg} \mathrm{Al} / \mathrm{L}$, due to colloid re-stabilization. This trend was not observed when using alum as a coagulant.

In the case of efficiency removal in terms of COD, NOM content (expressed as A254), and DOC, the positive effect of the operating temperature can be observed.

The removal efficiencies obtained for the DOC parameter are mostly within the expected limits based on the initial SUVA value $(<25 \%)$ [25], as shown in Figure 1a,b.

The NOM content decreased after coagulation, expressed by smaller values obtained at all the studied wavelengths $(254,280$, and $365 \mathrm{~nm}$ ) (Figure 1a,b). In general, the highest removal efficiencies of NOM $(33.33-52.08 \%)$ were registered at $365 \mathrm{~nm}$. The total NOM content, expressed as A254, was reduced between $8.27 \%$ and $25.26 \%$ vis-à-vis the value before coagulation. These reductions of the absorbance explain the higher values obtained in the example of the ratios A254/A280 and A254/A365 (Figure S1 in the Supplementary Materials).

It can be observed from Figure 1c that the SUVA values are quite close between the studied temperatures, especially at the $\mathrm{PACl}$ dose of $<4 \mathrm{mg} \mathrm{Al} / \mathrm{L}$. The correlation analysis shows a strong positive correlation between the SUVA and PACl dose at $4{ }^{\circ} \mathrm{C}$ (Figure S4a in the Supplementary Materials), which is explained by a marked increase in SUVA values up to $1.33 \mathrm{~L} /(\mathrm{mg} \cdot \mathrm{m})$ after a coagulant dose higher than $4 \mathrm{mg} \mathrm{Al} / \mathrm{L}$. However, a 
weak correlation was found between the same parameters at $20{ }^{\circ} \mathrm{C}$ (Figure S4b in the Supplementary Materials), owning to the SUVA values being closer to each other.

From the correlation analysis, the coagulant dose shows a strong negative correlation with the $\mathrm{DOC}$ and $\mathrm{pH}_{\mathrm{f}}$ at low temperature coagulation tests (Figure S4a). At a higher temperature, a strong negative correlation was found between the $\mathrm{PACl}$ dose and the values for $\mathrm{pH}_{\mathrm{f}}$ and the NOM content (Figure $\mathrm{S} 4 \mathrm{~b}$ ). The reader should be advised that the correlation analysis was performed by using the water quality indicator values and not the removal efficiency. This means that the sign of the correlation factor shown in Figure $\mathrm{S} 4 \mathrm{a}, \mathrm{b}$ will be the opposite to the trend presented in Figure 1a,b (i.e., a negative correlation coefficient means a positive dependency of removal efficiency).

The $\mathrm{pH}$ values, after the coagulation tests, decreased at a higher $\mathrm{PACl}$ dose, but not below the $\mathrm{pH}$ value of 7.58 (Figure 1c). The water $\mathrm{pH}$ influences both the efficiency of the coagulation process and the speciation of the NOM. At a neutral $\mathrm{pH}$ level, the dominant form of $\mathrm{Al}$ ions in an aqueous solution is aluminate, which is favorable for the charge neutralization of the dissolved NOM [10].

The residual aluminum in water was positively influenced by the pre-hydrolyzed coagulant dose $(r=0.54-0.72$, Figure $S 4 a, b)$ and the values after coagulation were over $403 \mu \mathrm{g} / \mathrm{L}$ (Figure 2). Similar values for the $\mathrm{PACl}$ coagulant were reported by [24].

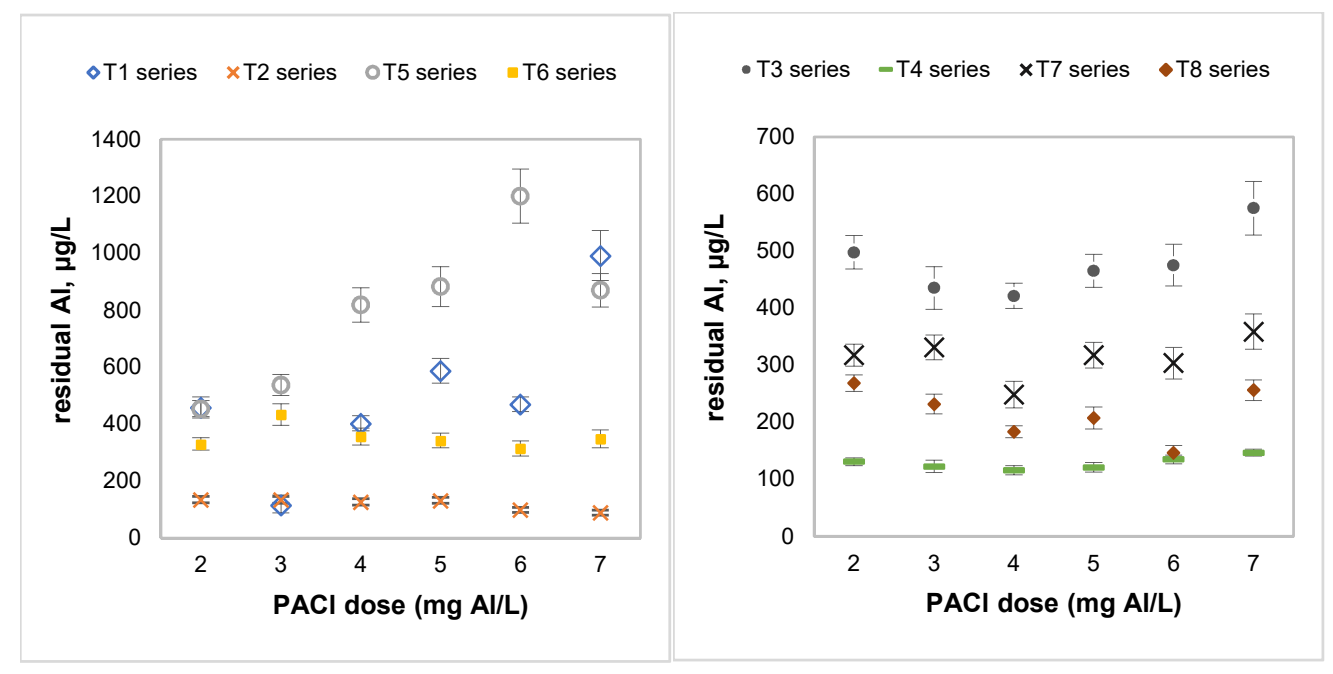

(a)

(b)

Figure 2. Residual aluminum after the coagulation-flocculation tests at: (a) $4{ }^{\circ} \mathrm{C}$ and (b) $20^{\circ} \mathrm{C}$.

\subsection{Influence of the Polyelectrolyte Addition}

Polyelectrolyte addition resulted in the forming of large, dense, and easily distinguished aggregates, which improved the settling rate. It was stated that an increased flocculation can be obtained as a result of bridge formation, when using an organic polyelectrolyte in the presence of an inorganic polymer with a high charge density [4]. The removal efficiencies in terms of the COD and DOC (Figure 3a,b) were two times higher than the values obtained from the coagulation experiments. In addition, as shown in Figure 2, the concentration of the residual aluminum was below $150 \mu \mathrm{g} / \mathrm{L}$, which is lower than the Romanian legislative requirements, i.e., $200 \mu \mathrm{g} / \mathrm{L}$. A study of the $\mathrm{PACl}$ application in the conventional treatment scheme (coagulation, sedimentation, and sand filtration) at a real scale was reported [26]. It was found that, in the presence of the high molecular weight anionic polyelectrolyte, the residual aluminum concentration was $60-90 \mu \mathrm{g} / \mathrm{L}$. 


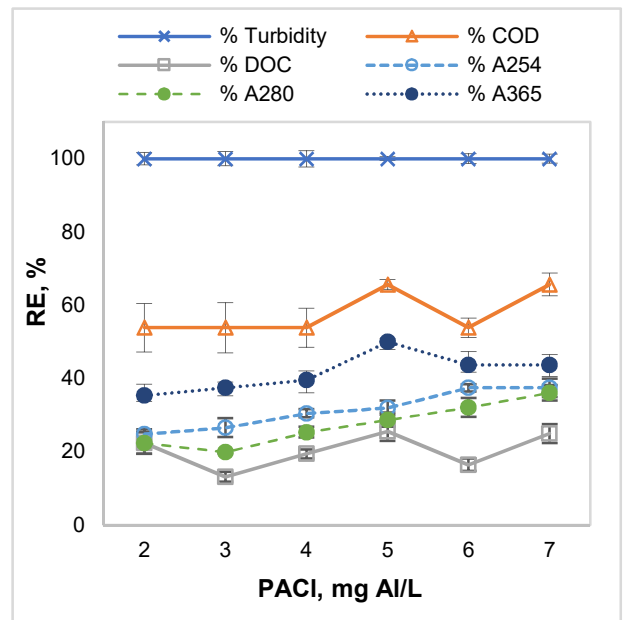

(a)

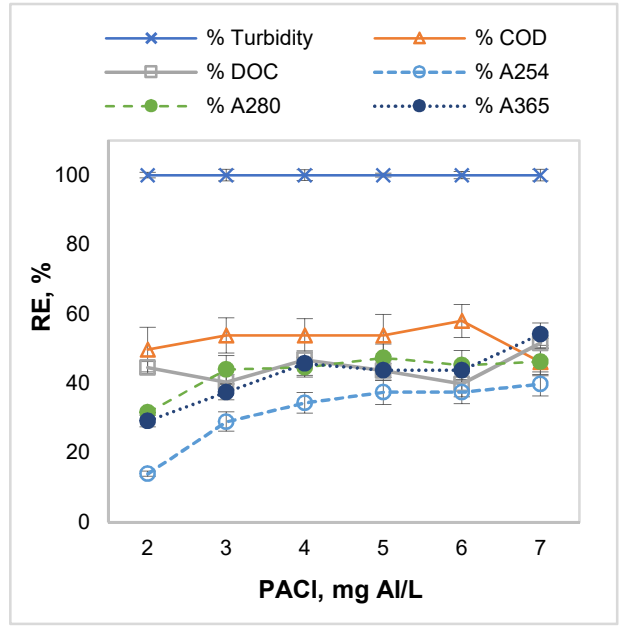

(b)

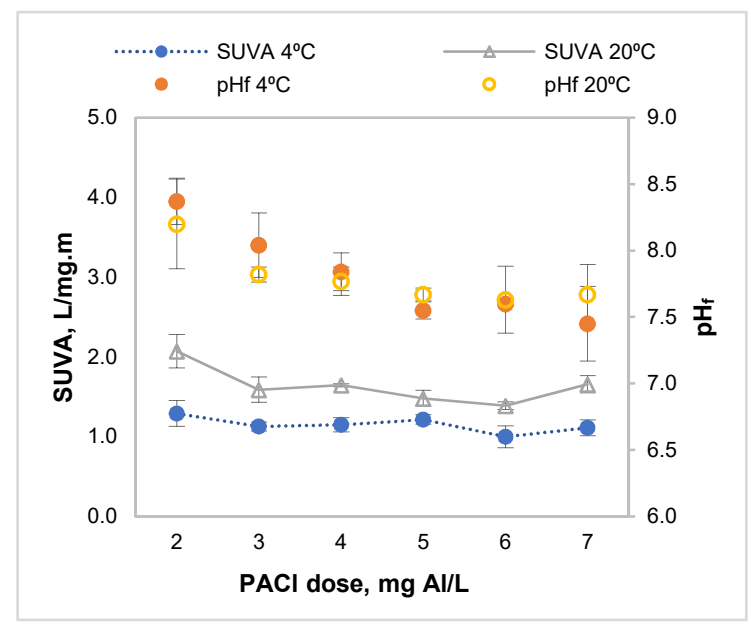

(c)

Figure 3. Removal efficiency of the coagulation-flocculation process at $4{ }^{\circ} \mathrm{C}$ (a) and $20^{\circ} \mathrm{C}(\mathbf{b})$, and the SUVA results (c) with polyelectrolyte addition.

Total NOM content, expressed as A254, was further reduced by up to approximately $40 \%$ at $20{ }^{\circ} \mathrm{C}$ (Figure 2a,b). A greater increase in NOM removal efficiency was observed at a low temperature, when comparing the removal efficiencies in terms of A254 and A280 (Figure 2a) with the experimental results from series T1 (Figure 1a). This fact may be explained by slower coagulation kinetics occurring at a low temperature $[27,28]$. The presence of a clarifying agent leads to improved sedimentation rates, by joining destabilized particles together and increasing their weight [29]. This proves the necessity of the addition of the polyelectrolyte, especially in cold weather conditions.

At $4{ }^{\circ} \mathrm{C}$, the SUVA values were lower than those obtained from the coagulation experiments, as seen in Figure 2c. An opposite trend can be observed for the SUVA values at $20^{\circ} \mathrm{C}$, due to the lower values obtained for the DOC.

In comparison with the coagulation tests, the content of high-molecular weight hydrophobic NOM fraction measured at $365 \mathrm{~nm}$ did not significantly reduce in the presence of the polyelectrolyte (Figure 2a,b). Thus, the lower values for the A254/A365 ratio are explained by the change in the A254 values (Figure S1 in the Supplementary Materials). Moreover, the ratio A254/A280 presents similar values to the results of the tests for series T1 and T3. 
In this case, the PACl influenced the residual $\mathrm{pH}$ and NOM content at both temperatures, presenting a strong negative correlation (Figure S5a,b in the Supplementary Materials).

\subsection{Influence of Mixing Conditions}

The mixing conditions (agitation time and mixing intensity) are important factors affecting the performance of the coagulation-flocculation process. In the rapid mixing stage, an efficient homogeneous dispersion of the polyelectrolyte should be performed in the shortest practicable time. Furthermore, the slow mixing allows for the collision between the small flocs, causing their subsequent aggregation, ideally without breaking. Mixing conditions that are either too high or too low result in flocculation that is only partial [30].

In order to investigate the influence of the agitation time, $\mathrm{C} / \mathrm{F}$ experiments were also performed at the short agitation time of $1.5 \mathrm{~min}$ at $300 \mathrm{rpm}$ for rapid mixing and $10 \mathrm{~min}$ at $60 \mathrm{rpm}$ for slow mixing, considering different coagulant doses and temperatures. The experimental results are illustrated in Figures S2 and S3 in the Supplementary Materials.

By reducing the mixing to approximately half of the agitation time, the removal efficiencies at a lower temperature were reduced, by average, with $5.8 \%$ for COD, $2.15 \%$ for DOC, and $5.7 \%$ for A280, compared to the RE\% at a longer agitation time (series T2, Figure S2a). Higher RE\% were obtained for the total NOM content (as A254) and the NOM fraction with a high molecular weight (as A365): $4.7 \%$ and 5.9\%, respectively (average values).

At $20{ }^{\circ} \mathrm{C}$, the $\mathrm{RE} \%$ for short time tests, i.e., series $\mathrm{T} 7$, were lower than series $\mathrm{T} 4$ (shown in Figure S2b) on average, with 1.6\% for COD, $7 \%$ for DOC, and $23 \%$ for the high-reactive NOM (as A280). The increase in the A280 values also explains the lower A254/A280 ratios obtained (Figure S1a). In this case, the RE\% also increased for A254 and A365 on average by $2 \%$ and $6.9 \%$, respectively.

The most noticeable effect of the short time agitation was observed on the residual aluminum concentrations (Figure 2). At a lower temperature, this indicator was found to be in the range of $454.6-1201.2 \mu \mathrm{g} / \mathrm{L}$, resulting in a 7.05-fold increase on average as compared to the results from $\mathrm{T} 1$ experimental series.

A strong negative correlation was found between the coagulant dose and NOM content at both temperatures studied (Figure S6a,b in the Supplementary Materials).

In order to study the mixing intensity, experiments at a lower mixing intensity (at $200 \mathrm{rpm}$ for rapid mixing and $25 \mathrm{rpm}$ for slow mixing) were also performed. The removal efficiencies of the water quality indicators are shown in Figure S3 in the Supplementary Materials. The RE\% in terms of COD were in the range of $45.56-60.36 \%$ at $4{ }^{\circ} \mathrm{C}$ and $45.56-63.91 \%$ at $20^{\circ} \mathrm{C}$, which are lower in general than the values obtained in series $\mathrm{T} 2$ and T4. Moreover, the removal efficiency expressed as DOC decreased by $14 \%$ and $23.9 \%$ at $4{ }^{\circ} \mathrm{C}$ and $20^{\circ} \mathrm{C}$, respectively.

Regarding the NOM content, differences were noticed for the high reactivity dissolved compounds (as A280) when the efficiency was reduced, on average, by $14.9 \%$ compared to the data from series T4 (Figure S3b). The residual Al also presented higher levels under a low mixing intensity, as shown in Figure 2.

The correlation analysis at both temperatures indicated that the $\mathrm{PACl}$ dose strongly correlated with the $\mathrm{pH}_{\mathrm{f}}$ and the NOM content (Figure S7a,b in the Supplementary Materials).

These results indicate the inadequate mixing conditions, causing an inhomogeneous distribution of the polyelectrolyte. It was reported by [30] that the slow mixing intensity positively influences the charge neutralization coagulation when compared to sweep flocculation. Moreover, charge neutralization coagulation requires a longer slow mixing duration.

Based on the results described until now, the optimum mixing conditions are $3 \mathrm{~min}$ at $300 \mathrm{rpm}$ for rapid mixing and $15 \mathrm{~min}$ at $60 \mathrm{rpm}$ for slow mixing. 


\subsection{Principal Component Analysis}

Principal component analysis was performed, first, for the tests at each temperature separately and, then, taking into account all tests.

The results of the PCA for the experiments performed in cold conditions (series T1, T2, T5, and T6) are presented in Figure S8 of the Supplementary Materials. It can be observed that PC1 captures $41.2 \%$ of the total variance, while PC2 captures $24.0 \%$, and PC 3 captures $20.0 \%$. PC1 is negatively correlated with all quality indicators. In Figure S8a, a cluster can be seen on the negative side of PC1, corresponding to the T1 experimental series, when no polyelectrolyte was added. The experiments using polyelectrolyte, namely T2, T5, and T6, have predominantly positive scores for PC1. Another distinguishable cluster is reflected in the T2 series, and has negative scores for PC2. This experimental series was performed under the same conditions as T1, but with the addition of polyelectrolyte.

PC2 presents a strong and positive influence of residual $\mathrm{Al}$ and $\mathrm{COD}$ and is affected negatively by A365. In Figure S8b, PC 3 shows a stronger positive influence by DOC and a smaller negative effect of A254 and A280. Here, we notice two clusters: the T2 series on the negative side of PC2 and the T6 series on the positive side of PC3. These experiments present the influence of mixing intensity. The wide spread of the T5 series (short mixing time) is due to higher values for residual $\mathrm{Al}$ and $\mathrm{A} 280$.

The principal component analysis of the experiments performed at $20^{\circ} \mathrm{C}$ also resulted in three principal components explaining the total variance in the experimental data (Figure S9 in Supplementary Materials). PC1 (41.5\%) is influenced negatively by all quality indicators, similar to the PCA results for the $\mathrm{C} / \mathrm{F}$ experiments at $4{ }^{\circ} \mathrm{C}$. A strong negative effect can be seen for A254, A365, and residual Al concentration. PC2 explains $21.6 \%$ of the variance and is positively influenced by DOC and A280. The third principal component can explain $17.3 \%$ of the variant and expresses a positive influence by COD and A280. In Figure S9a, the negative side of PC2 is related to low values for all the quality indicators and to the T4 experimental series, reflecting the optimal mixing conditions. The coagulation experiments (without the addition of polyelectrolyte) can be noticed separately on the negative side of $\mathrm{PC} 1$, while the $\mathrm{C} / \mathrm{F}$ tests are mainly aggregated on the positive side. The PCA plot in Figure S9b indicates a more noticeable discrimination of the experimental series, although T7 and T8 remain as a duo of bad mixing conditions.

When we consider the PCA for all tests at both temperatures, discrimination is not that readily seen, except for in a few tests, as shown in Figure 4a. PC1 explains 39.9\% of the total variance and is positively influenced by all the indicators considered. The second PC can explain $24.4 \%$ of the variance in the dataset. PC2 is positively influenced by $\mathrm{A} 254$ and A365 and negatively influenced by COD, A280, DOC, and the residual Al concentration.

The PCA at both temperatures corroborates with the optimal conditions of T2 (limited and at a dose of $>5 \mathrm{mg} \mathrm{Al} / \mathrm{L}$ ) and T4 tests, as they appear on the lower side of the parameters. On the opposite side, T1 and T5 (both at a low temperature) can be distinguished, due to the higher values of COD and A280, and the residual aluminum concentration, respectively. It can be observed that $\mathrm{T} 3$ at a higher dose of $\mathrm{PACl}$ is similar to $\mathrm{T} 2$ at a lower coagulant dose. This, once again, confirms the influence of ambient temperature and polyelectrolyte presence on the efficiency of the coagulation process.

In order to verify if further discrimination of the dataset is possible, another principal component, PC3, was considered (eigenvalue of 0.87$)$. PC3 (12.8\%) is negatively influenced by DOC and A365. Figure $4 \mathrm{~b}$ indicates that a segregation between T2 and T3 was indeed achieved. This occurred because of a lower influence of A254 on PC2 and PC3, than on PC1. 


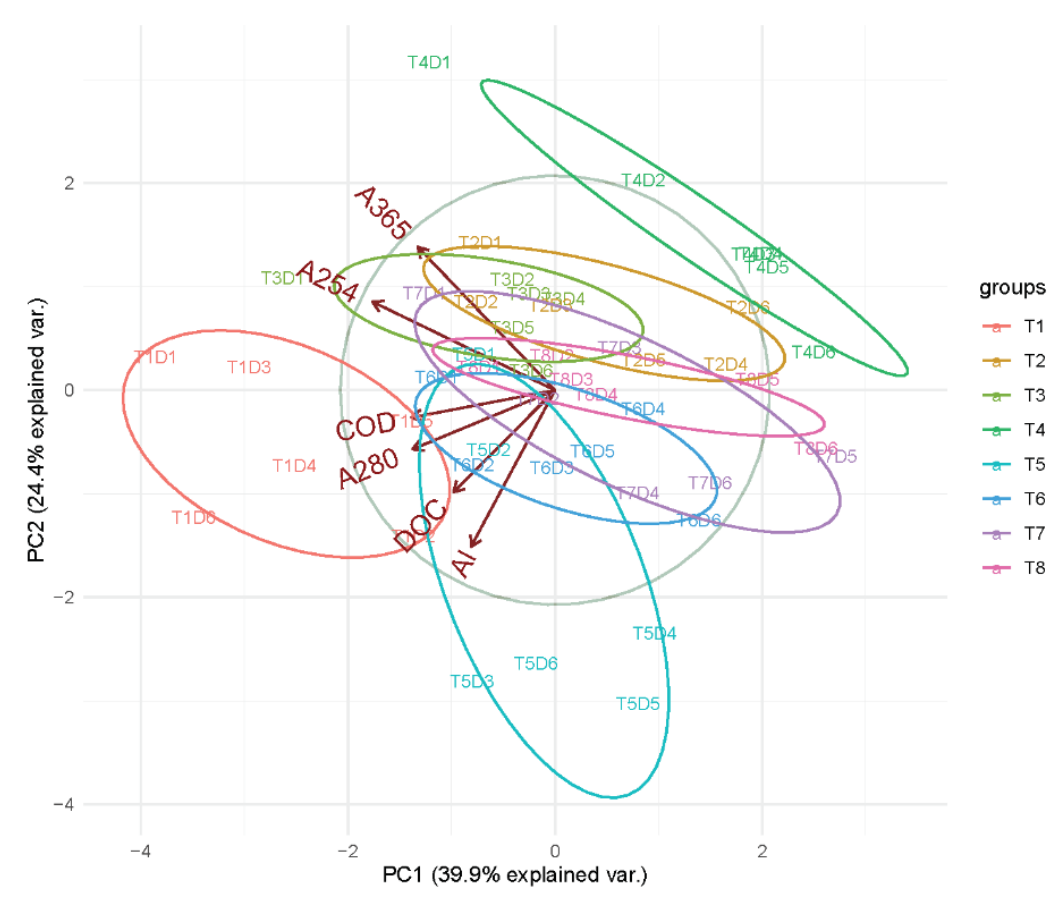

(a)

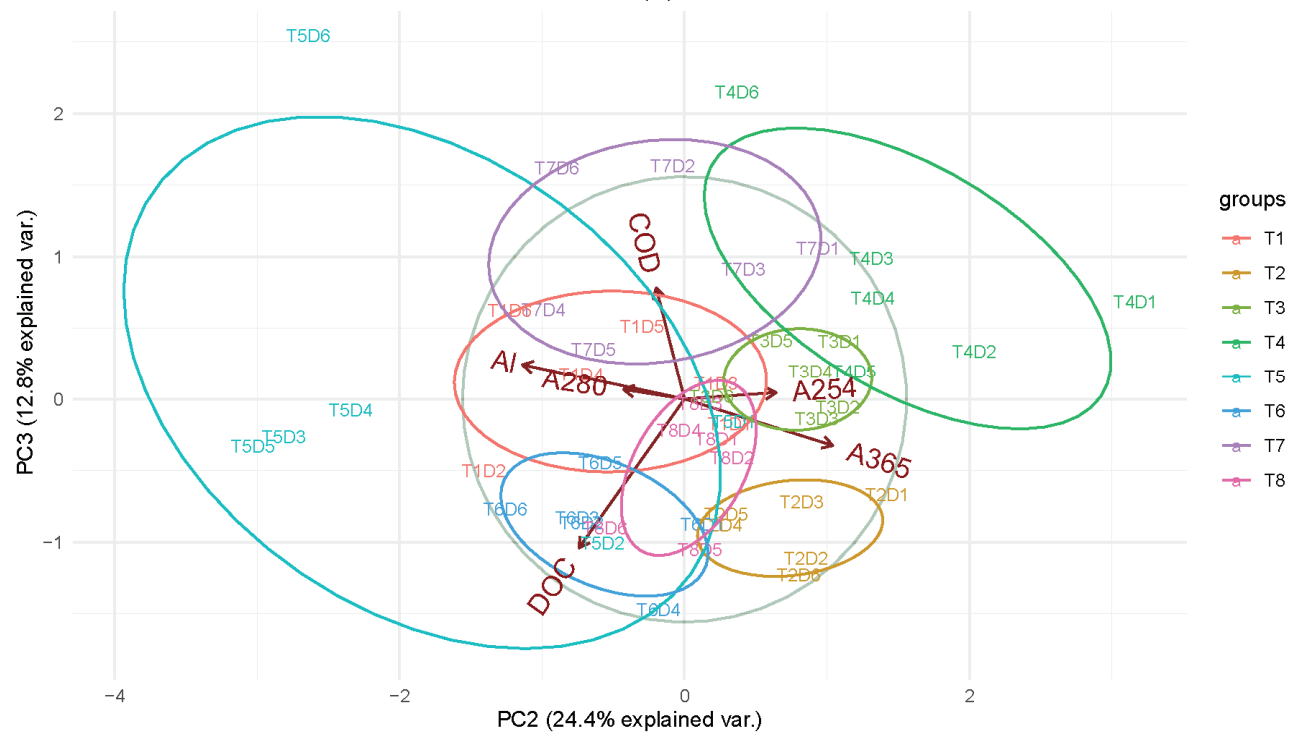

(b)

Figure 4. Principal component analysis for the coagulation-flocculation tests at both temperatures: (a) PC2 vs. PC1 and (b) PC3 vs. PC2. The notation D1 ... D6 represents the PACl dose in the range of $2-7 \mathrm{mg} \mathrm{Al} / \mathrm{L}$ with an increment of 1 .

\subsection{Selecting the Optimum Coagulant Dose}

In a coagulation-flocculation process, the coagulant dose is one of the decisive factors of influence to achieve a high NOM removal efficiency and to prevent the propagation of disinfection by-product precursors. Recently, Lapointe et al. [31] used NOM fractionation to establish the choice of coagulant, in order to reduce the presence of disinfection by-product precursors. In their optimization, humic substances (hydrophobic fraction) and their breakdown products (more hydrophilic in nature) were considered, together with traditional water parameters like: DOC (as a measure of total NOM), turbidity, and filterable $\mathrm{Al} / \mathrm{Fe}$. In our study, we considered UV absorbance at different wavelengths (at $254 \mathrm{~nm}, 280 \mathrm{~nm}, 365 \mathrm{~nm}$, and their ratios) to assess the optimal coagulant dose for water 
with low hydrophobicity. We found that, after coagulation, the SUVA values decreased compared to the initial value, suggesting the removal of unsaturated organic compounds from the water [32]. The lowest SUVA values corresponded to the lowest A254 values (reflective of lignin and humic compounds [17]) and the highest DOC values. If, at cold temperature, the SUVA levels decrease further after polyelectrolyte addition, in warm conditions, this parameter showed no significant change, despite the lower values of A254 and DOC. In this case, the absorbance values at $280 \mathrm{~nm}$ and $365 \mathrm{~nm}$ and, respectively, the ratios of A254/A280 and A254/A365 could be informative. As the absorbance values decreased, their relative contribution to the total NOM, expressed as A254, was higher (lower ratio values).

A280 is believed to be indicative of phenol, benzene, and amino acids [33], while A365 corresponds to humic compounds with a high molecular weight. The increase in A254 relative to A280 signifies an improved efficiency for these unsaturated compounds. In correlation with the lower values of A280, the higher values of the A254/A365 ratio may suggest an increase in the fraction of NOM with a high molecular weight, after the removal of some protein-like compounds.

The removal efficiency of A365 was higher than A280 for all coagulant doses in cold water, suggesting that a high molecular weight NOM requires a lower coagulant dose than the low molecular weight NOM. Since the former values have a predominantly higher proportion of negative charge per unit size and, hence, greater solubility, a higher dose of coagulant will be needed to achieve a higher driving force for the coagulation [4]. A similar situation can be described in the case of the first coagulant dose (i.e., $2 \mathrm{mg} \mathrm{Al} / \mathrm{L}$ ) for the experiments performed at a higher temperature.

For the selection of the optimum coagulant dose, we have considered the performance regarding the removal efficiencies for the more traditional quality indicators and the NOM content. In this evaluation, turbidity was excluded, based on the very high efficiency obtained, showing no influence in either choice. The evaluation of the optimal PACl dose is presented in Table S2 of the Supplementary Materials. According to the results, the PACl optimum dose was different at a lower temperature than at a higher one. A higher dose is necessary for a better $\mathrm{C} / \mathrm{F}$ performance in cold conditions. A minimum performance score was obtained for a dose of $7 \mathrm{mg} \mathrm{Al} / \mathrm{L}$; however, a dose of $5 \mathrm{mg} / \mathrm{L}$ is recommended for reasons relating to the cost and environmental impact. An optimum dose of $4 \mathrm{mg} \mathrm{Al} / \mathrm{L}$ was identified for warm water. Table 4 presents a short overview of Al-based coagulants used for the treatment of raw water that has specific characteristics, e.g., a low turbidity, and/or low temperature, and/or hydrophilic NOM, together with the considered water parameters to express the coagulation efficiency.

Table 4. Comparison with other studies from literature.

\begin{tabular}{|c|c|c|c|c|}
\hline Coagulant/Flocculant & Raw Water Characteristics & Optimum Coagulant Dose & Efficiency & Ref. \\
\hline $\mathrm{PACl}$ & $\begin{array}{l}\text { Low turbidity and DOC, hydrophilic NOM, } \\
\text { and low temperature }\end{array}$ & $10 \mathrm{mg} \mathrm{Al} / \mathrm{L}$ & $30 \%$ DOC, $40 \%$ A254, and $34 \%$ turbidity & [34] \\
\hline $\begin{array}{l}\mathrm{PACl} / \text { compound } \\
\text { bioflocculant }\end{array}$ & $\begin{array}{l}\text { Low turbidity and DOC, hydrophilic NOM, } \\
\text { and low temperature }\end{array}$ & $10 \mathrm{mg} \mathrm{Al} / \mathrm{L}$ & $29 \%$ DOC, $38 \%$ A254, and $40 \%$ turbidity & [34] \\
\hline $\mathrm{PACl}$ & Acid $\mathrm{pH}$ and turbidity $=9.5 \mathrm{NTU}$ & $40 \mathrm{mg} \mathrm{Al} / \mathrm{L}$ & $\begin{array}{c}78.5 \% \text { humic acids, } 75.6 \% \text { fulvic acids, and } \\
80.9 \% \text { turbidity }\end{array}$ & [10] \\
\hline Alum & High DOC and hydrophilic NOM & $8 \mathrm{mg} \mathrm{Al} / \mathrm{L}$ & $\begin{array}{l}23.5 \% \text { non-purgedable DOC, } 25 \% \text { A254, } \\
31.9 \% \text { trihalomethanes formation potential, } \\
\text { and } 25.4 \% \text { haloacetic acid } \\
\text { formation potential }\end{array}$ & [35] \\
\hline $\mathrm{AlCl}_{3}$ & $\begin{array}{l}\text { River water with turbidity }=151 \text { NTU } \\
\text { and } \mathrm{pH}=8.12\end{array}$ & $2.6 \mathrm{mg} \mathrm{Al} / \mathrm{L}$ & $63 \%$ turbidity & [36] \\
\hline $\mathrm{PACl}$ & $\begin{array}{l}\text { River water with turbidity }=151 \mathrm{NTU} \\
\text { and } \mathrm{pH}=8.12\end{array}$ & $1.3 \mathrm{mg} \mathrm{Al} / \mathrm{L}$ & $93 \%$ turbidity & [36] \\
\hline $\mathrm{PACl}-\mathrm{Al}_{13}$ & $\begin{array}{l}\text { River water with turbidity }=151 \mathrm{NTU} \\
\text { and } \mathrm{pH}=8.12\end{array}$ & $1.3 \mathrm{mg} \mathrm{Al} / \mathrm{L}$ & $95 \%$ turbidity & [36] \\
\hline $\mathrm{AlCl}_{3}$ & $\begin{array}{l}\text { Low turbidity and DOC, and } \\
\text { low temperature }\end{array}$ & $2.16 \mathrm{mg} \mathrm{Al} / \mathrm{L}$ & $\begin{array}{c}\text { 17.5\% DOC, residual dissolved } \\
\mathrm{Al}=0.4 \mathrm{mg} / \mathrm{L}\end{array}$ & [37] \\
\hline
\end{tabular}


Table 4. Cont.

\begin{tabular}{|c|c|c|c|c|}
\hline Coagulant/Flocculant & Raw Water Characteristics & Optimum Coagulant Dose & Efficiency & Ref. \\
\hline $\mathrm{Al}_{13}$ & $\begin{array}{l}\text { Low turbidity and DOC, and } \\
\text { low temperature }\end{array}$ & $2.16 \mathrm{mg} \mathrm{Al} / \mathrm{L}$ & $19 \%$ DOC, residual dissolved $\mathrm{Al}=0.2 \mathrm{mg} / \mathrm{L}$ & [37] \\
\hline $\mathrm{Al}_{30}$ & $\begin{array}{l}\text { Low turbidity and DOC, and } \\
\text { low temperature }\end{array}$ & $2.16 \mathrm{mg} \mathrm{Al} / \mathrm{L}$ & $17 \%$ DOC, residual dissolved $\mathrm{Al}=0.3 \mathrm{mg} / \mathrm{L}$ & [37] \\
\hline $\begin{array}{l}\text { Composite potassium } \\
\text { permanganate with } \\
\text { composite polymeric } \\
\text { aluminum ferric } \\
\text { chloride/poly-dimethyl- } \\
\text { diallyl- ammonium } \\
\text { chloride coagulant }\end{array}$ & $\begin{array}{l}\text { River water, low turbidity, } \\
\text { and low temperature }\end{array}$ & - & $\begin{array}{c}76.8 \% \text { turbidity, } 14.2 \% \text { oxygen consumption, } \\
60.8 \% \text { THM, and } 19.4 \% \text { absorbable } \\
\text { organic halogens }\end{array}$ & {$[38]$} \\
\hline $\mathrm{FeCl}_{3}$ & $\begin{array}{l}\text { River water, low turbidity, } \\
\text { and low temperature }\end{array}$ & $40 \mathrm{mg} / \mathrm{L}$ & $\begin{array}{c}72.4 \% \mathrm{~A} 254,11.5 \% \mathrm{COD} \text {, and residual } \\
\mathrm{Fe}=0.08 \mathrm{mg} / \mathrm{L}\end{array}$ & [39] \\
\hline $\begin{array}{c}\text { Polyaluminum ferric } \\
\text { chloride } / \mathrm{FeCl}_{3}(3: 1 \text { by mass) }\end{array}$ & $\begin{array}{l}\text { River water, low turbidity, } \\
\text { and low temperature }\end{array}$ & $20 \mathrm{mg}$ coagulant/L & $\begin{array}{c}84 \% \text { A254, } 43 \% \text { COD, and turbidity }<0.5 \\
\text { NTU, residual } \mathrm{Al}=0.09 \mathrm{mg} / \mathrm{L} \text {, and residual } \\
\mathrm{Fe}=0.01 \mathrm{mg} / \mathrm{L}\end{array}$ & [39] \\
\hline $\begin{array}{l}\text { Commercial PACl }(8 \% \\
\left.\mathrm{Al}_{\text {polymeric }}\right) / \mathrm{FeCl}_{3}(2: 1)\end{array}$ & Low turbidity & $18.8 \mathrm{mg} \mathrm{Al} / \mathrm{L}$ & $\begin{array}{l}81.28 \% \text { turbidity, and } \\
\text { residual dissolved } \mathrm{Al}=0.08 \mathrm{mg} / \mathrm{L}\end{array}$ & {$[40]$} \\
\hline $\begin{array}{l}\text { Commercial } \mathrm{PACl}(35 \% \\
\left.\mathrm{Al}_{\text {polymeric }}\right) / \mathrm{FeCl}_{3}(2: 1)\end{array}$ & Low turbidity & $18.8 \mathrm{mg} \mathrm{Al} / \mathrm{L}$ & $\begin{array}{l}81.92 \% \text { turbidity, and } \\
\text { residual dissolved } \mathrm{Al}=0.05 \mathrm{mg} / \mathrm{L}\end{array}$ & {$[40]$} \\
\hline $\operatorname{PACl}(90.3 \%$ basicity)/chitosan & $\begin{array}{c}\text { Reservoir water, low temperature, } \\
\text { and low turbidity }\end{array}$ & $8 \mathrm{mg} \mathrm{Al}_{2} \mathrm{O}_{3} / \mathrm{L}$ & $\begin{array}{c}87 \% \text { turbidity, } 63 \% \text { DOC, } 82 \% \text { A254, and } \\
\text { residual } \mathrm{Al}<0.15 \mathrm{mg} / \mathrm{L}\end{array}$ & [14] \\
\hline $\mathrm{PACl} /$ anionic polyacrilamide & $\begin{array}{l}\text { River water, low temperature, low turbidity, } \\
\text { and hydrophilic NOM }\end{array}$ & $7 \mathrm{mg} \mathrm{Al} / \mathrm{L}$ & $\begin{array}{c}100 \% \text { turbidity, } 65.68 \% \mathrm{COD}, 24.94 \% \mathrm{DOC} \\
37.44 \% \mathrm{~A} 254,36.06 \% \mathrm{~A} 280,43.75 \% \mathrm{~A} 365 \\
\text { and residual } \mathrm{Al}=0.09 \mathrm{mg} / \mathrm{L}\end{array}$ & $\begin{array}{l}\text { This } \\
\text { study }\end{array}$ \\
\hline $\mathrm{PACl} /$ anionic polyacrilamide & $\begin{array}{l}\text { River water, high temperature, low } \\
\text { turbidity, and hydrophilic NOM }\end{array}$ & $4 \mathrm{mg} \mathrm{Al} / \mathrm{L}$ & $\begin{array}{c}100 \% \text { turbidity, } 53.85 \% \text { COD, } 46.79 \% \text { DOC, } \\
34.44 \% \text { A254, } 44.65 \% \mathrm{~A} 280,45.83 \% \mathrm{~A} 365 \\
\text { and residual } \mathrm{Al}=0.12 \mathrm{mg} / \mathrm{L}\end{array}$ & $\begin{array}{l}\text { This } \\
\text { study }\end{array}$ \\
\hline
\end{tabular}

\section{Conclusions}

In this study, the efficiency of coagulation-flocculation for removing NOM from Prut River water was investigated.

Turbidity was removed completely after coagulation, with or without coagulant aid. The coagulant dose in the range of $2-7 \mathrm{mg} \mathrm{Al} / \mathrm{L}$ did not generate an effluent $\mathrm{pH}$ value lower than 7, while the residual aluminum concentration was affected by the PACl dose, mixing conditions, and temperature.

The coagulant aid (polyelectrolyte) used to improve the effluent quality, decreased the values for all indicators. This trend was more noticeable for the coagulation-flocculation process at a lower temperature.

A shorter agitation time and lower mixing intensity produced inconsistent results, as some of the indicators, like DOC, COD, and A280, presented, on average, lower values than the optimum conditions tests. Moreover, the water quality was improved in terms of residual aluminum, A254, and A365.

The coagulant dose was found to be strongly correlated with different effluent quality indicators, depending on temperature, agitation time, and mixing intensity. Under optimum mixing conditions and in the presence of the coagulant aid, $\mathrm{PACl}$ dose manifested a strong negative influence on the NOM content (expressed as A254, A280, and A365), and the effluent $\mathrm{pH}$, respectively. In cold conditions, the residual aluminum concentration in the water was also significantly impacted by the variation of coagulant dosage.

The principal component analysis showed that the efficiency of coagulation-flocculation experiments performed at non-optimal mixing conditions were similar to the coagulation experiments without the coagulant aid. The $\mathrm{C} / \mathrm{F}$ at optimal working conditions discriminated from the other tests. Further work is necessary to relate these findings with the coagulation-flocculation mechanisms.

Supplementary Materials: The following materials are available online at https: / www.mdpi.com/ article/10.3390/w13213073/s1, Figure S1: Absorbance ratios after the coagulation-flocculation tests: (a) A254/A280 ratio, (b) A254/A365; Figure S2: Removal efficiency of coagulation-flocculation process at $4{ }^{\circ} \mathrm{C}$ (a) and $20{ }^{\circ} \mathrm{C}$ (b) under short agitation time; Figure S3: Removal efficiency of coagulation-flocculation process at $4{ }^{\circ} \mathrm{C}$ (a) and $20{ }^{\circ} \mathrm{C}$ (b) under low mixing intensity; Figure S4: Correlation plots for test series T1 (a) and T3; Figure S5: Correlation plots for test series T2 (a) and T4 
(b); Figure S6: Correlation plots for test series T5 (a) and T7 (b); Figure S7: Correlation plots for test series T6 (a) and T8 (b); Figure S8: Principal component analysis for coagulation-flocculation tests at $4{ }^{\circ} \mathrm{C}$ : (a) PC2 vs PC1 and (b) PC3 vs PC2; Figure S9: Principal component analysis for coagulationflocculation tests at $20^{\circ} \mathrm{C}$ : (a) PC2 vs PC1 and (b) PC3 vs PC2; Table S1: Characteristics of PAX XL 60 coagulant used; Table S2: Coagulation-flocculation efficiency scores considering multiple water quality indicators.

Author Contributions: Conceptualization, C.P.M., I.M., and C.T.; methodology, C.P.M., I.M., and C.T.; validation, I.M., C.P.M., and M.A.-R.; formal analysis, I.M., C.P.M., and M.A.-R.; investigation, I.M., R.C., A.G., O.P., and I.R.; data curation, I.M.; writing-original draft preparation, C.P.M., and I.M.; writing-review and editing, C.T.; supervision, C.T.; project administration, C.P.M., and C.T.; funding acquisition, C.T., and C.P.M. All authors have read and agreed to the published version of the manuscript.

Funding: This research was funded by a grant from the Ministry of Research, Innovation and Digitization, CNCS/CCCDI-UEFISCDI, project number PN-III-P2-2.1-PED-2019-1996, within PNCDI III.

Institutional Review Board Statement: Not applicable.

Informed Consent Statement: Not applicable.

Data Availability Statement: Not applicable.

Conflicts of Interest: The authors declare no conflict of interest.

\section{References}

1. Sillanpää, M.; Matilainen, A.; Lahtinen, T. Characterization of NOM. In Natural Organic Matter in Water; Elsevier: Amsterdam, The Netherlands, 2015; pp. 17-53. ISBN 9780128015032.

2. Adusei-Gyamfi, J.; Ouddane, B.; Rietveld, L.; Cornard, J.-P.; Criquet, J. Natural organic matter-cations complexation and its impact on water treatment: A critical review. Water Res. 2019, 160, 130-147. [CrossRef]

3. Jones, A.N.; Bridgeman, J. A fluorescence-based assessment of the fate of organic matter in water treated using crude/purified Hibiscus seeds as coagulant in drinking water treatment. Sci. Total Environ. 2019, 646, 1-10. [CrossRef]

4. Dayarathne, H.N.; Angove, M.J.; Aryal, R.; Abuel-Naga, H.; Mainali, B. Removal of natural organic matter from source water: Review on coagulants, dual coagulation, alternative coagulants, and mechanisms. J. Water Process Eng. 2021, 40, 101820. [CrossRef]

5. Brezinski, K.; Gorczyca, B. Multi-spectral characterization of natural organic matter (NOM) from Manitoba surface waters using high performance size exclusion chromatography (HPSEC). Chemosphere 2019, 225, 53-64. [CrossRef] [PubMed]

6. Sillanpää, M.; Ncibi, M.C.; Matilainen, A.; Vepsäläinen, M. Removal of natural organic matter in drinking water treatment by coagulation: A comprehensive review. Chemosphere 2018, 190, 54-71. [CrossRef] [PubMed]

7. Gilca, A.F.; Teodosiu, C.; Fiore, S.; Musteret, C.P. Emerging disinfection byproducts: A review on their occurrence and control in drinking water treatment processes. Chemosphere 2020, 259, 127476. [CrossRef]

8. Directive (EU) 2020/2184 of the European Parliament and of the Council of 16 December 2020 on the Quality of Water Intended for Human Consumption (Recast), OJ L 435, 23.12.2020, pp. 1-62. Available online: https://eur-lex.europa.eu/eli/dir/2020/2184/oj (accessed on 10 June 2021).

9. Xiao, F.; Ma, J.; Yi, P.; Huang, J.-C.H. Effects of low temperature on coagulation of kaolinite suspensions. Water Res. 2008, 42, 2983-2992. [CrossRef]

10. Go, R.J.C.; Yang, H.L.; Kan, C.C.; Ong, D.C.; Garcia-Segura, S.; de Luna, M.D.G. Natural organic matter removal from raw surface water: Benchmarking performance of chemical coagulants through excitation-emission fluorescence matrix spectroscopy analysis. Water 2021, 13, 146. [CrossRef]

11. Wang, C.; Alpatova, A.; McPhedran, K.N.; Gamal El-Din, M. Coagulation/flocculation process with polyaluminum chloride for the remediation of oil sands process-affected water: Performance and mechanism study. J. Environ. Manag. 2015, 160, 254-262. [CrossRef] [PubMed]

12. Yan, M.; Wang, D.; Ni, J.; Qu, J.; Chow, C.W.K.; Liu, H. Mechanism of natural organic matter removal by polyaluminum chloride: Effect of coagulant particle size and hydrolysis kinetics. Water Res. 2008, 42, 3361-3370. [CrossRef]

13. Lin, J.-L.; Huang, C.; Chin, C.-J.M.; Pan, J.R. Coagulation dynamics of fractal flocs induced by enmeshment and electrostatic patch mechanisms. Water Res. 2008, 42, 4457-4466. [CrossRef] [PubMed]

14. Zhang, Z.; Jing, R.; He, S.; Qian, J.; Zhang, K.; Ma, G.; Chang, X.; Zhang, M.; Li, Y. Coagulation of low temperature and low turbidity water: Adjusting basicity of polyaluminum chloride (PAC) and using chitosan as coagulant aid. Sep. Purif. Technol. 2018, 206, 131-139. [CrossRef]

15. Zhao, Y.X.; Phuntsho, S.; Gao, B.Y.; Yang, Y.Z.; Kim, J.-H.; Shon, H.K. Comparison of a novel polytitanium chloride coagulant with polyaluminium chloride: Coagulation performance and floc characteristics. J. Environ. Manag. 2015, 147, 194-202. [CrossRef]

16. Yan, M.; Wang, D.; Yu, J.; Ni, J.; Edwards, M.; Qu, J. Enhanced coagulation with polyaluminum chlorides: Role of pH/Alkalinity and speciation. Chemosphere 2008, 71, 1665-1673. [CrossRef] 
17. Yang, Z.; Gao, B.; Cao, B.; $\mathrm{Xu}, \mathrm{W}$; Yue, Q. Effect of $\mathrm{OH}^{-} / \mathrm{Al}^{3+}$ ratio on the coagulation behavior and residual aluminum speciation of polyaluminum chloride (PAC) in surface water treatment. Sep. Purif. Technol. 2011, 80, 59-66. [CrossRef]

18. Pan, Y.; Li, H.; Zhang, X.; Li, A. Characterization of natural organic matter in drinking water: Sample preparation and analytical approaches. Trends Environ. Anal. Chem. 2016, 12, 23-30. [CrossRef]

19. Masu, S.; Burtica, G.; Manea, F.; Pisoi, I. Spectrophotometric parameters for organic matter characterization in raw and treated surface water. Environ. Eng. Manag. J. 2011, 10, 1451-1457. [CrossRef]

20. Matilainen, A.; Gjessing, E.T.; Lahtinen, T.; Hed, L.; Bhatnagar, A.; Sillanpää, M. An overview of the methods used in the characterisation of natural organic matter (NOM) in relation to drinking water treatment. Chemosphere 2011, 83, 1431-1442. [CrossRef] [PubMed]

21. Law 458/2002 on Drinking Water Quality, Modified and Republished in Romanian Official Monitor No. 705, Bucharest, Romania. Available online: http:/ / legislatie.just.ro/Public/DetaliiDocument/37723 (accessed on 26 May 2021).

22. RStudio. RStudio: Integrated Development for R; RStudio: Boston, MA, USA, 2021.

23. Boubchir, M.; Aourag, H. Materials genome project: The application of principal component analysis to the formability of perovskites and inverse perovskites. Comput. Condens. Matter 2020, 24, e00495. [CrossRef]

24. Iriarte-Velasco, U.; Álvarez-Uriarte, J.I.; González-Velasco, J.R. Enhanced coagulation under changing alkalinity-hardness conditions and its implications on trihalomethane precursors removal and relationship with UV absorbance. Sep. Purif. Technol. 2007, 55, 368-380. [CrossRef]

25. Edzwald, J.K.; Tobiason, J.E. Enhanced coagulation: Us requirements and a broader view. Water Sci. Technol. 1999, 40, 63-70. [CrossRef]

26. Zouboulis, A.; Traskas, G.; Samaras, P. Comparison of Efficiency between Poly-aluminium Chloride and Aluminium Sulphate Coagulants during Full-scale Experiments in a Drinking Water Treatment Plant. Sep. Sci. Technol. 2008, 43, 1507-1519. [CrossRef]

27. Qiao, G.; Zhang, J.; Zhang, Q.; Feng, X.; Lu, Y.; Feng, W. The Influence of Temperature on the Bulk Settling of Cohesive Sediment in Still Water with the Lattice Boltzmann Method. Water 2019, 11, 945. [CrossRef]

28. Fitzpatrick, C.S.B.; Fradin, E.; Gregory, J. Temperature effects on flocculation, using different coagulants. Water Sci. Technol. 2004, 50, 171-175. [CrossRef]

29. Maćczak, P.; Kaczmarek, H.; Ziegler-Borowska, M. Recent Achievements in Polymer Bio-Based Flocculants for Water Treatment. Materials 2020, 13, 3951. [CrossRef]

30. Zhang, Z.; Liu, D.; Hu, D.; Li, D.; Ren, X.; Cheng, Y.; Luan, Z. Effects of slow-mixing on the coagulation performance of polyaluminum chloride (PACI). Chin. J. Chem. Eng. 2013, 21, 318-323. [CrossRef]

31. Lapointe, M.; Papineau, I.; Peldszus, S.; Peleato, N.; Barbeau, B. Identifying the best coagulant for simultaneous water treatment objectives: Interactions of mononuclear and polynuclear aluminum species with different natural organic matter fractions. J. Water Process Eng. 2021, 40, 101829. [CrossRef]

32. Zhao, Y.X.; Gao, B.Y.; Shon, H.K.; Cao, B.C.; Kim, J.-H. Coagulation characteristics of titanium (Ti) salt coagulant compared with aluminum (Al) and iron (Fe) salts. J. Hazard. Mater. 2011, 185, 1536-1542. [CrossRef] [PubMed]

33. Ytow, N.; Utsumi, M.; Seki, H. UV spectrometry for measuring particulate organic matter in natural water. Aquat. Sci. 1996, 58, 91-102. [CrossRef]

34. Huang, X.; Sun, S.; Gao, B.; Yue, Q.; Wang, Y.; Li, Q. Coagulation behavior and floc properties of compound bioflocculantpolyaluminum chloride dual-coagulants and polymeric aluminum in low temperature surface water treatment. J. Environ. Sci. 2015, 30, 215-222. [CrossRef]

35. Hidayah, E.N.; Chou, Y.-C.; Yeh, H.-H. Characterization and removal of natural organic matter from slow sand filter effluent followed by alum coagulation. Appl. Water Sci. 2018, 8, 3. [CrossRef]

36. Gao, B.-Y.; Chu, Y.-B.; Yue, Q.-Y.; Wang, B.-J.; Wang, S.-G. Characterization and coagulation of a polyaluminum chloride (PAC) coagulant with high Al13 content. J. Environ. Manag. 2005, 76, 143-147. [CrossRef] [PubMed]

37. Duan, S.-X.; Xu, H.; Xiao, F.; Wang, D.-S.; Ye, C.-Q.; Jiao, R.-Y.; Liu, Y.-G. Effects of Al species on coagulation efficiency, residual Al and floc properties in surface water treatment. Colloids Surf. A Physicochem. Eng. Asp. 2014, 459, 14-21. [CrossRef]

38. Song, W.C.; Li, X.; Sun, S.H.; Yang, Y.L.; Jia, R.B. Test Study of Enhanced Coagulation for Conventional Treatment with Low Temperature and Low Turbidity. J. Residuals Sci. Technol. 2015, S39-S46. [CrossRef]

39. Lou, I.; Gong, S.; Huang, X.; Liu, Y. Coagulation optimization for low temperature and low turbidity source water using combined coagulants: A case study. Desalin. Water Treat. 2012, 46, 107-114. [CrossRef]

40. Lin, J.-L.; Ika, A.R. Effect of Al speciation on residual turbidity and Al minimization by coagulation with single and dual dosing. J. Water Supply Res. Technol. 2019, 68, 51-62. [CrossRef] 